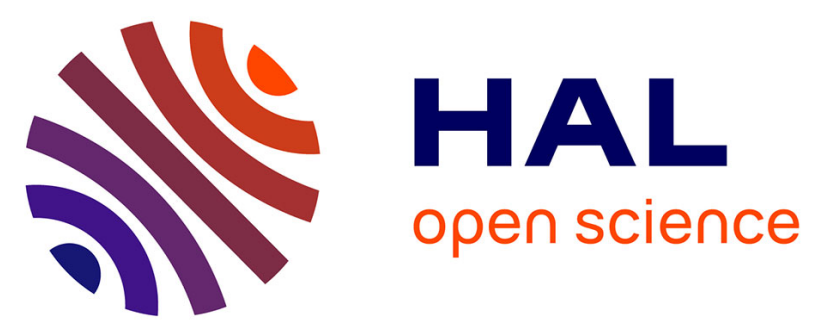

\title{
Evolution of the accretion processes along the Mid-Atlantic Ridge north of the Azores since 5.5 Ma: An insight into the interactions between the ridge and the plume
}

\author{
Marcia Maia, Jean Goslin, Pascal Gente
}

\section{To cite this version:}

Marcia Maia, Jean Goslin, Pascal Gente. Evolution of the accretion processes along the Mid-Atlantic Ridge north of the Azores since 5.5 Ma: An insight into the interactions between the ridge and the plume. Geochemistry, Geophysics, Geosystems, 2007, 8 (3), pp.Q03013. 10.1029/2006GC001318 . hal-00140487

\section{HAL Id: hal-00140487 \\ https://hal.science/hal-00140487}

Submitted on 15 Feb 2011

HAL is a multi-disciplinary open access archive for the deposit and dissemination of scientific research documents, whether they are published or not. The documents may come from teaching and research institutions in France or abroad, or from public or private research centers.
L'archive ouverte pluridisciplinaire HAL, est destinée au dépôt et à la diffusion de documents scientifiques de niveau recherche, publiés ou non, émanant des établissements d'enseignement et de recherche français ou étrangers, des laboratoires publics ou privés. 


\title{
Evolution of the accretion processes along the Mid-Atlantic Ridge north of the Azores since 5.5 Ma: An insight into the interactions between the ridge and the plume
}

\author{
Marcia Maia, Jean Goslin, and Pascal Gente \\ CNRS UMR 6538 Domaines Océaniques, IUEM, Place Nicolas Copernic, F-29280 Plouzané, France \\ (marcia@univ-brest.fr)
}

[1] High-resolution bathymetry and gravity data north of the Azores Plateau show that this part of the North Mid-Atlantic Ridge is presently undergoing a phase of weak crustal production and magmatism. Most of the ridge segments are small and short-lived, suggesting a disrupted and highly variable accretion regime since anomaly 3A. The influence of the nearby plume appears to be relatively minor and corresponds more to a weak thermal signal than to any major input of plume material and increased crustal production at the axis. A period of increased magmatism was identified at the southern limit of the study area $\left(\right.$ near $\left.40^{\circ} \mathrm{N}\right)$ around anomaly 5. This magmatic "pulse" caused the emplacement of a topographic high, probably underlain by a thickened crust. This pulse probably marks the northernmost and last significant arrival of material from the Azores plume to the MAR axis.

Components: 9597 words, 10 figures, 5 tables.

Keywords: mid-oceanic ridges; hot spots; Azores; ridge-hot spot interaction; ridge segmentation.

Index Terms: 3035 Marine Geology and Geophysics: Midocean ridge processes; 3045 Marine Geology and Geophysics: Seafloor morphology, geology, and geophysics.

Received 28 March 2006; Revised 3 October 2006; Accepted 13 November 2006; Published 22 March 2007.

Maia, M., J. Goslin, and P. Gente (2007), Evolution of the accretion processes along the Mid-Atlantic Ridge north of the Azores since 5.5 Ma: An insight into the interactions between the ridge and the plume, Geochem. Geophys. Geosyst., 8, Q03013, doi:10.1029/2006GC001318.

\section{Introduction}

[2] Mantle plumes have been recognized to influence the processes acting along mid-oceanic ridges [Vogt, 1976; Schilling, 1985, 1991]. As a consequence, the structure and composition of the oceanic crust created at the ridge axis may depend on the dynamics of the interaction between the ridge and a neighboring mantle plume [e.g., Schilling, 1985, 1991; Ito and Lin, 1995a, 1995b; Maia et al., 2000]. The nature of the plume influence at the ridge axis is most probably twofold: a regional large scale thermal anomaly, linked to the excess temperature induced in the upper mantle by the plume [e.g., Ito and Lin, 1995b; Ito et al., 1996] and a flow of the plume material along and across the ridge axis [e.g., Vogt, 1976; Morgan, 1978; Schilling, 1991; Ito et al., 1996]. Several ridge-hot spot systems were shown to have resulted in spatial and time variations in the crustal production at the ridge under the influence of the plume [e.g., Schilling, 1991; Ito and Lin, 1995a, 1995b; Maia et al., 2000; Escartin et al., 2001; Detrick et al., 2002]. Some 
ridge-hot spot systems have also been studied through the analysis of the off-axis volcanism produced during the interaction between the hot spot and the ridge [Kingsley and Schilling, 1998; Pan and Batiza, 1998; Maia et al., 2001]. Together with numerical and laboratory models [Kincaid et al., 1995, 1996; Ribe et al., 1995; Ribe, 1996; Ribe and Delattre, 1998; Ito et al., 1996] these studies helped to understand the spatial and temporal dynamics of the interaction between a ridge and a hot spot. The relative movement between the ridge and the plume appears as a major factor controlling the dynamics of the interaction [Ribe and Delattre, 1998; Ito et al., 1996; Ito and Lin, 1995b; Maia et al., 2000, 2001; Gente et al., 2003], together with temporal variations in the plume flux [Schilling, 1991; Ribe and Delattre, 1998; Ito et al., 1996; Cannat et al., 1999].

[3] The North Mid-Atlantic Ridge is presently under the influence of two major mantle plumes located beneath or close to the axis, Iceland and the Azores, which influence the crustal accretion processes [Vogt, 1976; White et al., 1976; White and Schilling, 1978; Schilling et al., 1977; Ito and Lin, 1995a; Ito et al., 1996; Goslin and the Triatnord Scientific Party, 1999; Goslin et al., 1998; Cannat et al., 1999; Gente et al., 2003]. The chemical composition of the basalts sampled along the MAR axis clearly shows the contribution of an enriched component attributed to the plumes [Schilling, 1975; White et al., 1976; Schilling et al., 1983; Bourdon et al., 1996; Yu et al., 1997; Dosso et al., 1999]. The ridge morphology and crustal structure also reflect the influence of the Azores and of Iceland [e.g., Vogt, 1976] which appears to be asymmetric. For Iceland, the Reikjanes ridge apparently results from the southward flow of plume material along the axis while north of Iceland, a similar feature does not exist, the eventual mantle flow being probably dammed by the Tjornes Fracture Zone. A similar asymmetry of the influence of the Azores plume along the MidAtlantic Ridge (MAR) axis has been proposed through the interpretation of different data sets [Goslin and the Triatnord Scientific Party, 1999; Goslin et al., 1998]. The plume influence along the MAR axis seems to extend further away southward from the Azores platform than it does northward [Detrick et al., 1995; Thibaud et al., 1998; Goslin and the Triatnord Scientific Party, 1999]. This influence appears as a long wavelength trend, with shallower zero-age depths and more negative
Mantle Bouguer anomalies centered on the Azores Plateau [Thibaud et al., 1998]. This trend is limited to the south roughly by the $27^{\circ} \mathrm{N}$ latitude [Thibaud et al., 1998]. Goslin and the Triatnord Scientific Party [1999] suggest that the northward limit of the Azores influence would correspond to a major relay zone near $43^{\circ} 40^{\prime} \mathrm{N}$ although different authors suggest that this limit is located further north, near Charles Gibbs Fracture Zone [Kurz et al., 1982]. North of the Azores, Mello et al. [1999] suggested the presence of an anomalous mantle beneath $45^{\circ} \mathrm{N}$, that could explain the flat trend in the free air anomaly as opposed to the trend in the bathymetry. The influence of the Azores could then be limited to this latitude. The long wavelength of the along-axis topography and MBA roughly corresponds to a gradient in the chemical composition of the axial lavas, although the steeper chemical gradient appears to be located closer to the Azores [Dosso et al., 1999] than is shown by other observables. The morpho-structural studies of Detrick et al. [1995] and Thibaud et al. [1998] along the MAR south of the Azores show that the characteristics of the individual accretion segments, i.e., their morphology and crustal structure, do not directly relate to the distance to the plume but instead reflect processes inherent to each segment. However, north of the $27^{\circ} \mathrm{N}$ latitude, the traces of the off-axis discontinuities systematically point south, away from the Azores Plateau. This, together with the long wavelength trend observed in the axial topography and in the Mantle Bouguer anomaly, would reflect the influence of the Azores plume along the ridge axis. This influence would either result in a southward asthenospheric flow away from the hot spot or in the presence of a horizontal density gradient in the mantle under the ridge axial domain [Vogt, 1976; Thibaud et al., 1998; Mello et al., 1999].

[4] Studies carried on south of the Azores platform [Vogt, 1976, 1979; Cannat et al., 1999; Escartin et al., 2001] showed the existence of an off-axis rifted plateau, named the Jussieu Plateau, which is linked to the Princess Alice Plateau, a prominent topographic high located on the eastern flank of the ridge by a series of oblique ridges. This ancient plateau reflects excess crust and shallow topography corresponding to higher mantle temperatures beneath the ridge axis due to the past influence of the Azores plume. The emplacement of the Princess Alice - Jussieu Plateau occurred between anomalies 5 and 4 and its rifting between anomalies 4 and 3 [Cannat et al., 1999]. Crustal thick- 


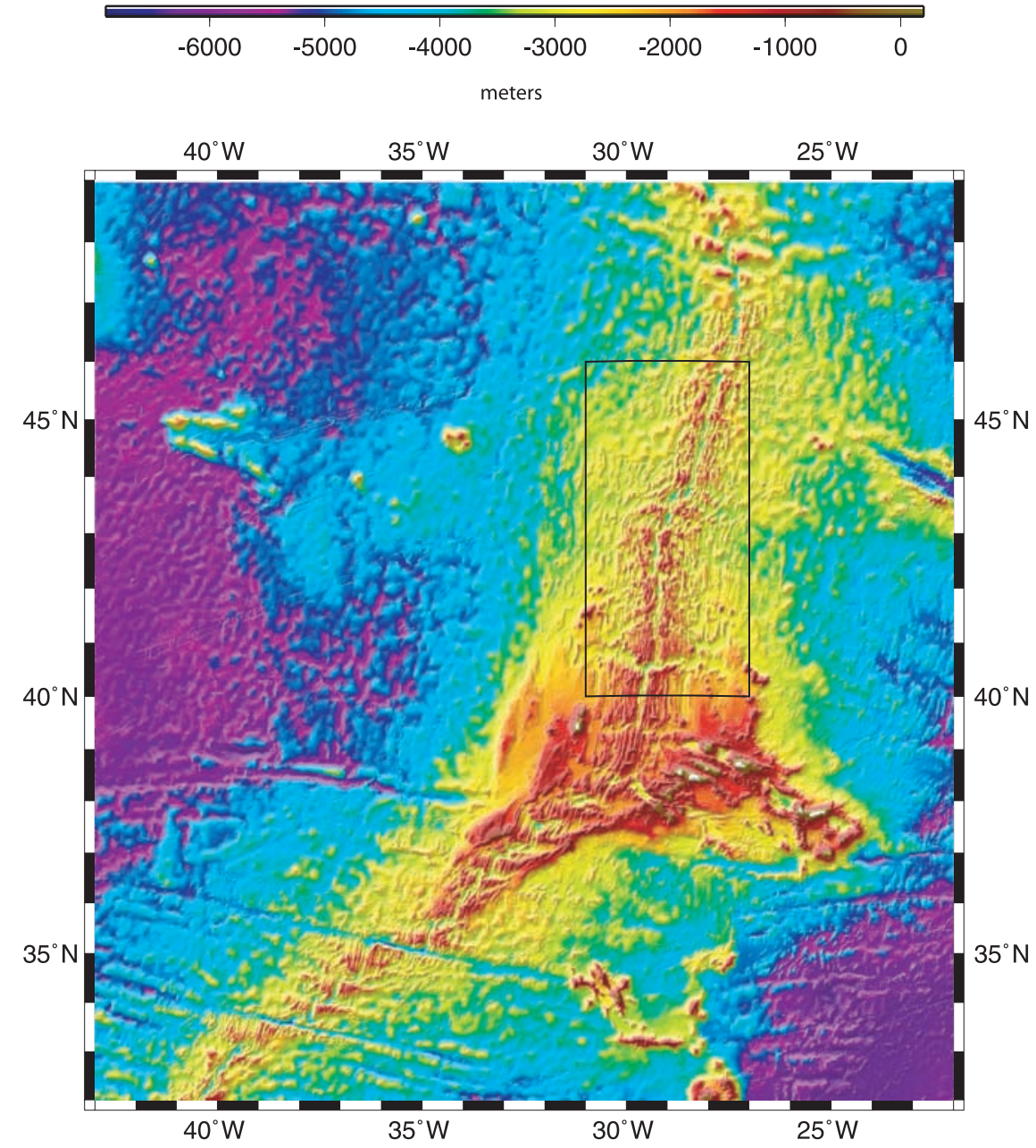

Figure 1. Bathymetry of the North Mid-Atlantic Ridge [Gente et al., 2003] showing the location of the study area.

ness reaches 12 to $14 \mathrm{~km}$ beneath the plateau, to be compared to $7-8 \mathrm{~km}$ values at the present-day ridge axis at the same latitude [Cannat et al., 1999; Escartin et al., 2001]. The building and subsequent rifting of the plateau is not synchronous alongridge and is interpreted as resulting from a southward migrating melt anomaly related to an along-axis mantle flow away from the Azores plume [Cannat et al., 1999].

[5] The objectives of this study are twofold. First, to investigate, using the regional bathymetry compilation (Figure 1) published by Gente et al. [2003] and free air satellite data [Sandwell and Smith, 1997], whether the magmatic pulse forming the Princess Alice - Jussieu Plateau south of the Azores [Cannat et al., 1999] has a northward component. Second, to evaluate the influence of the Azores hot spot at the Mid-Atlantic Ridge north of the Azores during the last 5 Myr by studying the axial and offaxis crustal structure using gravity and bathymetry data. For this last objective, detailed data acquired during the Triatnord cruise [Goslin et al., 1998] will be used. The data set covers the ridge axis and its flanks up to anomaly $3 \mathrm{~A}(5.54 \mathrm{Ma})$ and extends between $40^{\circ} \mathrm{N}$ and $45^{\circ} \mathrm{N}$ (Figure 1) and is described in the next session. Both objectives are important to evaluate the asymmetry of the influence of the Azores at the MAR during the last $10 \mathrm{~m} . \mathrm{y}$.

\section{Bathymetry and Gravity Data Set From the Triatnord Cruise}

[6] During the Triatnord cruise, a full bathymetry coverage of the recent domain of the MAR was obtained with a SIMRAD EM-12 dual multibeam 
echo sounder with 162 beams and with a ping repetition rate of $20 \mathrm{~s}$. Precision is 2 to $3 \%$ of the water depth. For most of the surveyed area, the track spacing (5 to 10 miles) allowed redundant seafloor coverage by the outermost beams. The final seafloor topography grid used for the study of the ridge morphology was computed with a $250 \mathrm{~m}$ grid spacing, using a near-neighbor algorithm (CARAIBES software, IFREMER). A second bathymetric grid was computed with a continuous curvature gridding algorithm (GMT software [Wessel and Smith, 1998]) and a coarser grid interval $(1.0 \mathrm{~km})$ over $1024 \times 1024$ points and used for gravity modeling. To fill the data gaps on the grid boundaries, in order to perform Fourier analysis, we completed the multibeam data set with data from the NOAA data bank and data from the ETOPO5 world bathymetry grid. This minimizes the spurious effects that might arise from edge effects due to the absence of shipboard data near the grid boundaries.

[7] Gravity data were acquired with a Bodenseewerk KSS-30 shipboard gravity meter at a $10 \mathrm{~s}$ sampling rate, corresponding to an along-track spacing of 50 meters at 10 knots, and corrected for instrument drift and for the Eotvös effect. The WGRS80 gravity reference field was removed from the corrected measurements to obtain the free air anomaly. The cross-over errors were calculated for the whole data set. After minimization, the final data STD error is less than $1.2 \mathrm{mGal}$. The data were smoothed by filtering with a Gaussian filter over ten to fifteen points, depending on the noise level (sea state, ship heading) and interpolated to obtain a final along-track sampling at 1 minute intervals, corresponding to $0.3 \mathrm{~km}$. The variable track spacing (5-10 miles, $\sim 9-18 \mathrm{~km})$ precludes the construction of a detailed free air anomaly grid from surface data only. A merged satellite-ship free air anomaly grid [Sandwell and Smith, 1997] was therefore constructed, with the shortest resolvable wavelengths of $20-25 \mathrm{~km}$. This merging not only fills the data gaps associated with the track spacing but also reduces the directional artifacts that may arise from the orientation of the profiles. Ship data contain more short-wavelength information along the tracks than do the satellite data. In order to improve the merging of the two data sets we first calculated the difference between the satellite and ship free air data at each measurement point along the profiles (D. T. Sandwell, personal communication, 1997). These differences were then gridded at a $1 \mathrm{~km}$ grid step using a continuous curvature algorithm [Wessel and Smith, 1998] and the gridded values added to the satellite-only grid. This results in a smooth grid that also conveniently matches the ship gravity measurements.

\section{Comparison Between the MAR North and South of the Azores Plateau: North Counterpart of the Princess Alice Plateau}

[8] It was proposed that the influence of the Azores plume along the ridge axis south of the Azores platform has varied both in space and time [Cannat et al., 1999; Escartin et al., 2001]. Magmatism reached a maximum between anomalies 5 and $3 \mathrm{~A}$, building the thick-crust Princess Alice - Jussieu Plateau, and decreased considerably between anomaly 3 and present. As a consequence, the plateaus were rifted and a "normal" accreting regime, with well identified ridge segments resumed [Escartin et al., 2001]. In order to investigate the possible existence of a northern counterpart to this major magmatic pulse, we calculate a residual bathymetry (Figure 2a) using the regional bathymetric compilation and the age grid of Gente et al. [2003] as well as a residual Mantle Bouguer Anomaly (MBA) using satellite derived free air anomalies (Figure 2b). Satellite derived data can be used for regional studies although the lack of high frequencies [Maia, 2006] precludes a detailed analysis of the crustal structure as performed by Escartin et al. [2001] for the Princess Alice - Jussieu Plateau.

[9] For the MBA calculations, crustal thickness is assumed to be constant $(6 \mathrm{~km})$ and the gravity effect of both the topography and the Moho interfaces are computed and removed from the free air anomaly [e.g., Kuo and Forsyth, 1988; Detrick et al., 1995]. Densities are also kept constant for both the crust and mantle, respectively $2800 \mathrm{~kg} / \mathrm{m}^{3}$ and $3300 \mathrm{~kg} / \mathrm{m}^{3}$ [e.g., Kuo and Forsyth, 1988]. Mantle Bouguer anomalies can be interpreted as deviations from this simple model, either as crustal thickness variations or as different crustal and/or mantle densities. The gravity effect of the model was computed using the three-dimensional multilayer method [Maia and Arkani-Hamed, 2002]. The MBA is dominated by the long wavelength component related to lithosphere cooling away from the ridge axis. This causes the anomalies to be more negative at the axis. In order to remove this thermal contribution from the MBA, we calculated the gravity effect of a cooling lithosphere, using a method developed by Rommevaux et al. [1994]. In this method, the depth of a density interface 

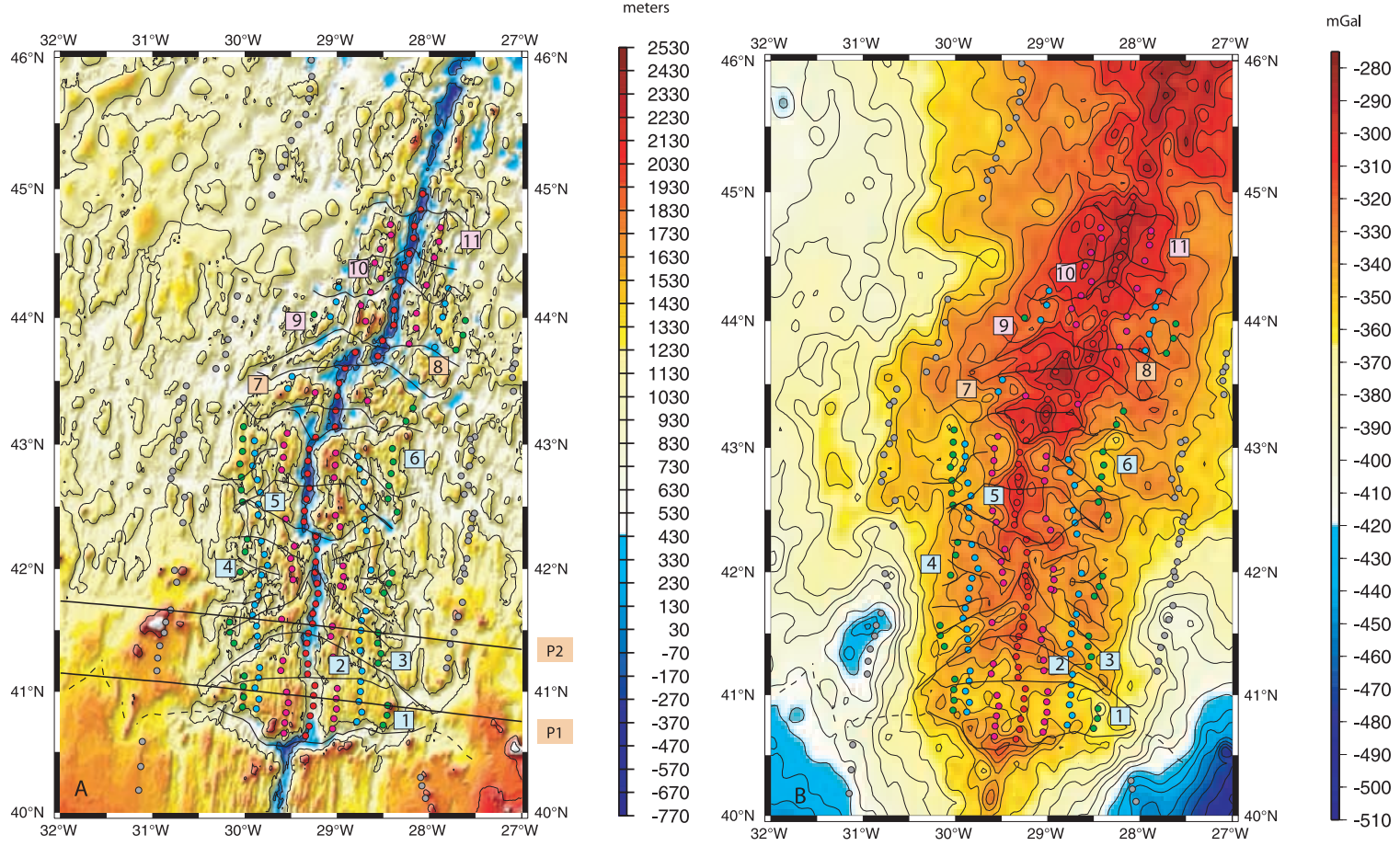

Figure 2. (a) Residual bathymetry north of the Azores platform computed from the bathymetry and age compilation of Gente et al. [2003]. The locations of the profiles plotted in Figure 3 are indicated by the black lines. (b) RMBA computed from the bathymetry compilation of Gente et al. [2003] and from the satellite free air anomalies. The thermal effect was removed using the method described in section 2. The colored dots show the locations of the identified magnetic anomalies. Colors correspond as follows: red to the ridge axis, magenta to anomaly 2 , light blue to anomaly 3 , green to anomaly $3 \mathrm{~A}$, and gray to anomaly 5 . Segment boundaries and past discontinuities identified in the study area are shown by the thin black lines. The thin dashed line shows the continuation of the Kurchatov Fracture Zone as seen for crust older than anomaly 3A. Segments are numbered from south to north. Blue shades in the numbered boxes correspond to segments from the south domain, orange corresponds to segments from the relay zone, and magenta corresponds to segments from the north domain.

following the base of the lithosphere is calculated from an age grid. A density contrast of $-60 \mathrm{~kg} / \mathrm{m}^{3}$ between the lithosphere and the asthenosphere is then assumed and the gravity effect corresponding to the cooling of the plate is computed [Rommevaux et al., 1994]. This method has the advantage of conveniently accounting for spreading asymmetries and changes in the ridge trend, being better suited for regional studies than the passive flow method of Phipps Morgan and Forsyth [1988], where a constant ridge geometry is adopted. A comparison between both methods show that, in the absence of large transforms and of highly variable ridge geometry, the amplitude and the trend of the thermal signal computed by both methods are equivalent [Rommevaux et al., 1994]. The effect of the thermal subsidence is also removed from the topography, yielding a residual bathymetry. The subsidence is computed from the same age grid using the law proposed by Parsons and Sclater [1977] with a value of $365 \mathrm{~m} / \mathrm{m}$.y. for the subsidence coefficient [Stein and Stein, 1992].
[10] Immediately north of the Azores platform, anomaly 5 corresponds to a bathymetric high, with smooth morphology associated with a pronounced RMBA low extending up to $\sim 42^{\circ} \mathrm{N}$. In Figure 3, we show two synthetic profiles across this high. This feature, although of smaller size, is probably the northern counterpart of the Princess Alice Plateau, which was formed around anomaly 5 [Cannat et al., 1999]. The axial magmatism therefore also reached a peak around this time north of the Azores platform, albeit with a weaker intensity. As a consequence, the topography high north of the Azores platform is smaller than its southern counterpart. The identification of magnetic anomaly 5 on both flanks of the ridge favors the hypothesis of an axial emplacement during a phase of intense magmatism and crustal production. The Kurchatov Fracture Zone, which separates this topographic high from the Azores platform, can be followed off-axis for crust older than anomaly 5, especially on the western flank of the ridge, strengthening the hypothesis of an axial emplacement. Following this 
P2
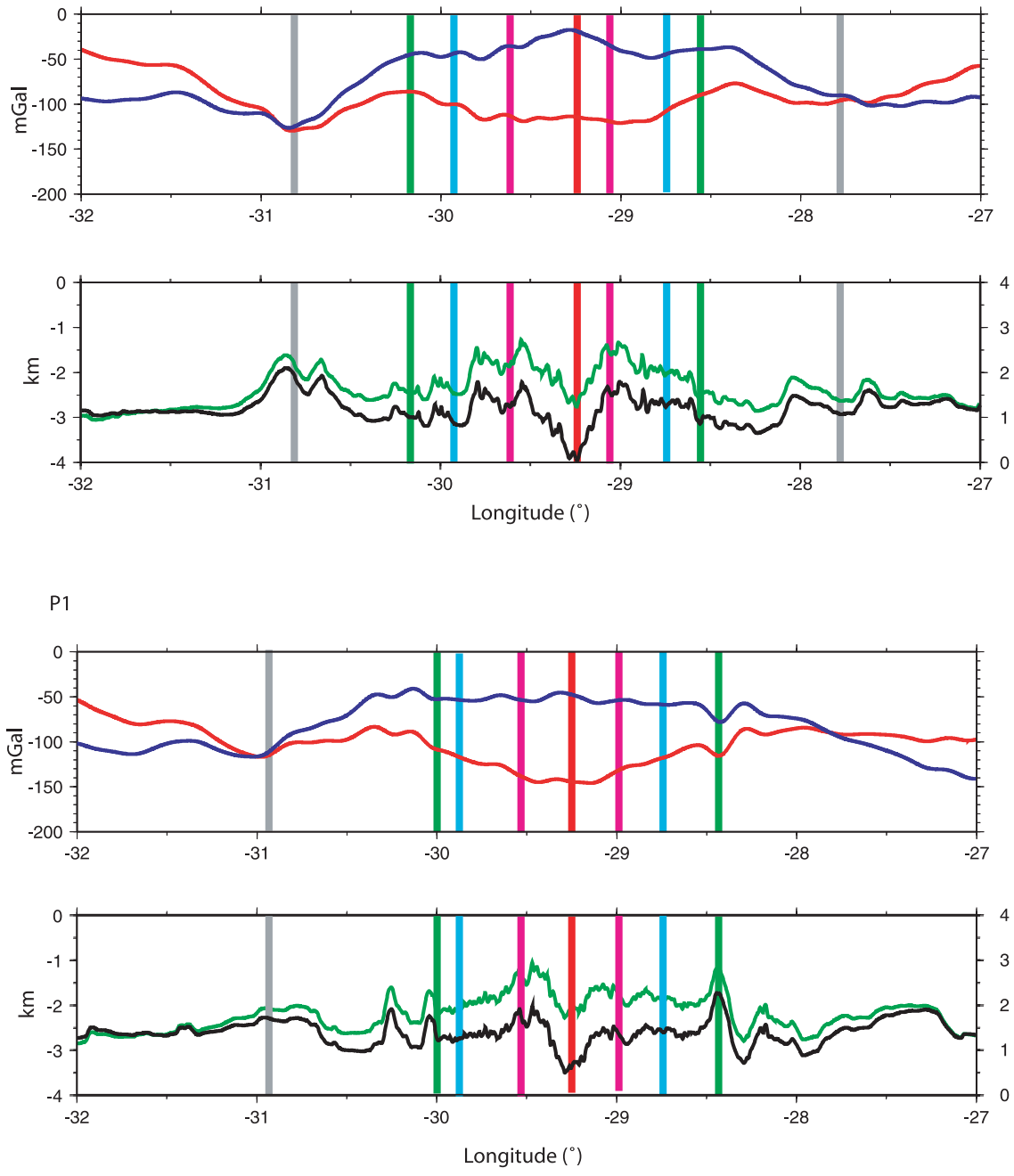

Figure 3. Bathymetry (black), residual bathymetry (green), MBA (red) and RMBA (blue) for profiles 1 and 2. The colored bars correspond to the locations of the magnetic anomalies.

major pulse, the magmatic production quickly decreased north of the Azores after anomaly 5, resulting in a "normal" accretion regime around anomaly 4 . This change in the ridge regime results in an increase in the roughness of the seafloor fabric and corresponds to the initiation of a more marked ridge segmentation (Figures 2 and 3).

[11] After the emplacement on axis of the Princess Alice Plateau, the magmatic pulse propagated southward, building oblique ridges and the Jussieu Plateau [Escartin et al., 2001]. North of the Azores Plateau we do not observe any comparable sign of fast along-axis propagation of plume material. The topographic high emplaced around anomaly 5 is of small dimensions. If it resulted from an episode of increased input of plume material at the ridge axis, then this episode was apparently short-lived and the hot spot material did not propagate north of $42-42^{\circ} 30^{\prime} \mathrm{N}$, where no traces of an older off-axis plateau or ridges are visible (Figure 2). The flow of hot spot material appears to be directed mainly southward, resulting in a north-south asymmetry of the Azores influence on the ridge axis at a given time.

\section{Morphology and Crustal Structure of the Mid-Atlantic Ridge North of the Azores Plateau Between Anomaly $3 \mathrm{~A}$ and the Present}

\subsection{Axial and Off-Axis Ridge Segmentation and Morphology}

[12] The multibeam bathymetry grid obtained with the data discussed in section 2 is displayed in 

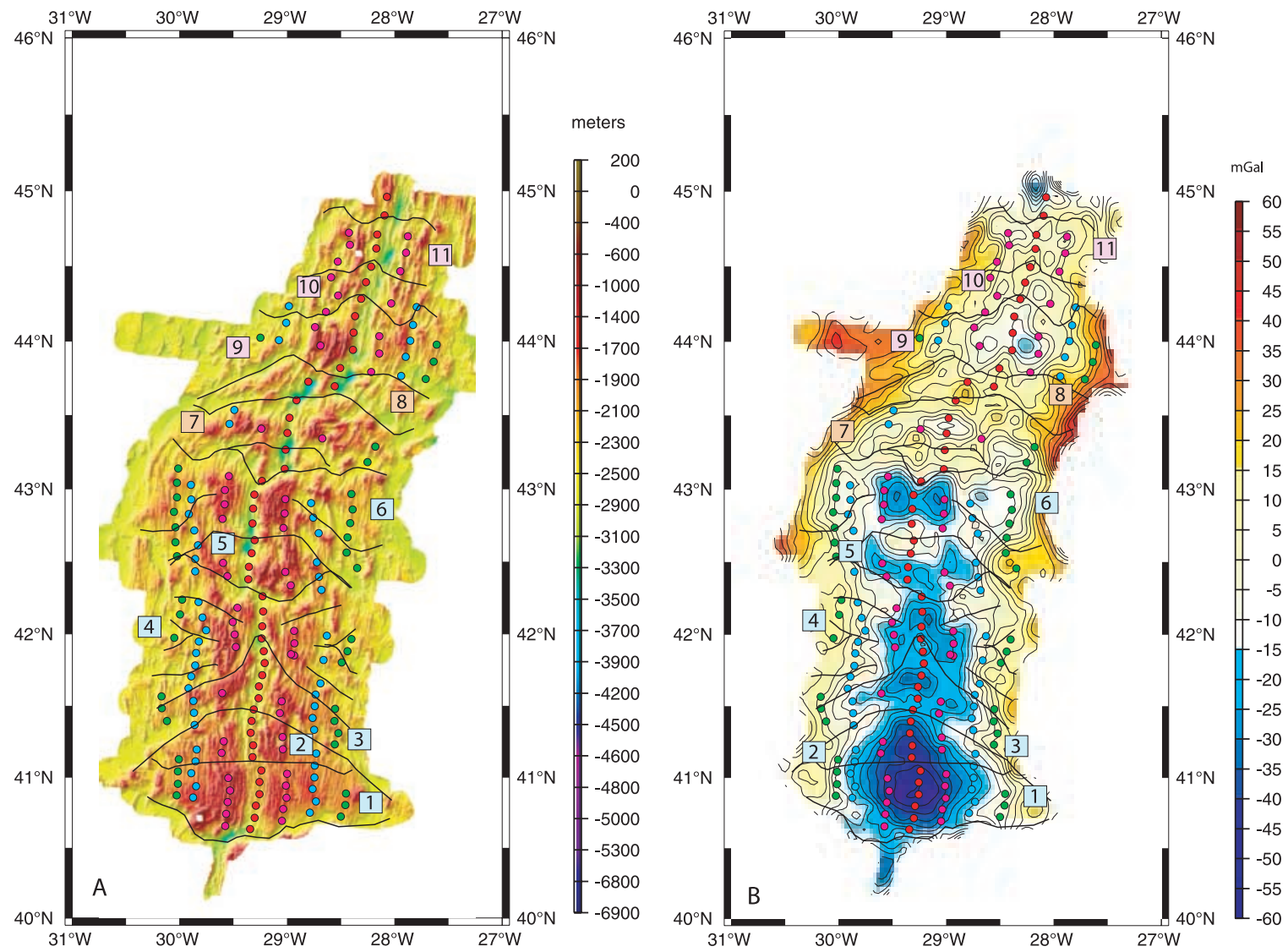

Figure 4. (a) Multibeam bathymetry of the North Mid-Atlantic Ridge from the TRIATNORD survey illuminated from the north and from the west. (b) Mantle Bouguer anomalies north of the Azores platform. Magnetic anomaly identifications are shown by colored dots. Colors correspond as follows: red to the ridge axis, magenta to anomaly 2 , light blue to anomaly 3 , and green to anomaly $3 \mathrm{~A}$. Segment boundaries and past discontinuities identified in the study area are shown by the thin black lines.

Figure 4a. Three domains are identified using the axial and off-axis morphology. Ridge segments are determined following previous works on the MAR segmentation [e.g., Gente et al., 1995; Pariso et al., 1995; Maia and Gente, 1998]. Segment centers and paleo-centers are characterized by topographic highs and MBA lows while segments boundaries are determined by topographic lows and MBA highs. The first, south of $43^{\circ} 05^{\prime} \mathrm{N}$ is formed by six segments with lengths varying between 30 and $55 \mathrm{~km}$. These segments are bounded by "V"shaped oblique discontinuities corresponding to small axial offsets (5 to $18 \mathrm{~km}$ ). The discontinuities are formed by elongated depressions oblique to the ridge trend or by series of transverse-trending basins aligned obliquely with respect to the ridge direction. The abyssal hills morphology changes from south to north. The three southern segments display low, regularly spaced hills, while the three northern segments are characterized by high and widely spaced relieves, less regularly distributed. The axial valley morphology varies accordingly, being shallower and narrower in the three southern segments. The off-axis ridge segmentation pattern shows a complex time evolution (Figures 4 and 5). The three southernmost segments are similar to other typical MAR segments, forming rhomboid shapes [e.g., Gente et al., 1995; Pariso et al., 1995; Thibaud et al., 1998]. The southernmost and first segment, located north of the Kurchatov Fracture Zone, is the longest and most robust segment of this domain and has been continuously lengthening since $5 \mathrm{~m}$.y. Its northern limit is marked by a $\sim 9 \mathrm{~km}$ axial offset which corresponds to a poorly marked off-axis discontinuity. The shape of the southern boundary shows that this segment lengthens mainly southward. Segment 2 started to lengthen around anomaly $3 \mathrm{~A}$ and is bounded to the north by a discontinuity forming a northward pointing "V". This segment appears to have lengthened mainly 

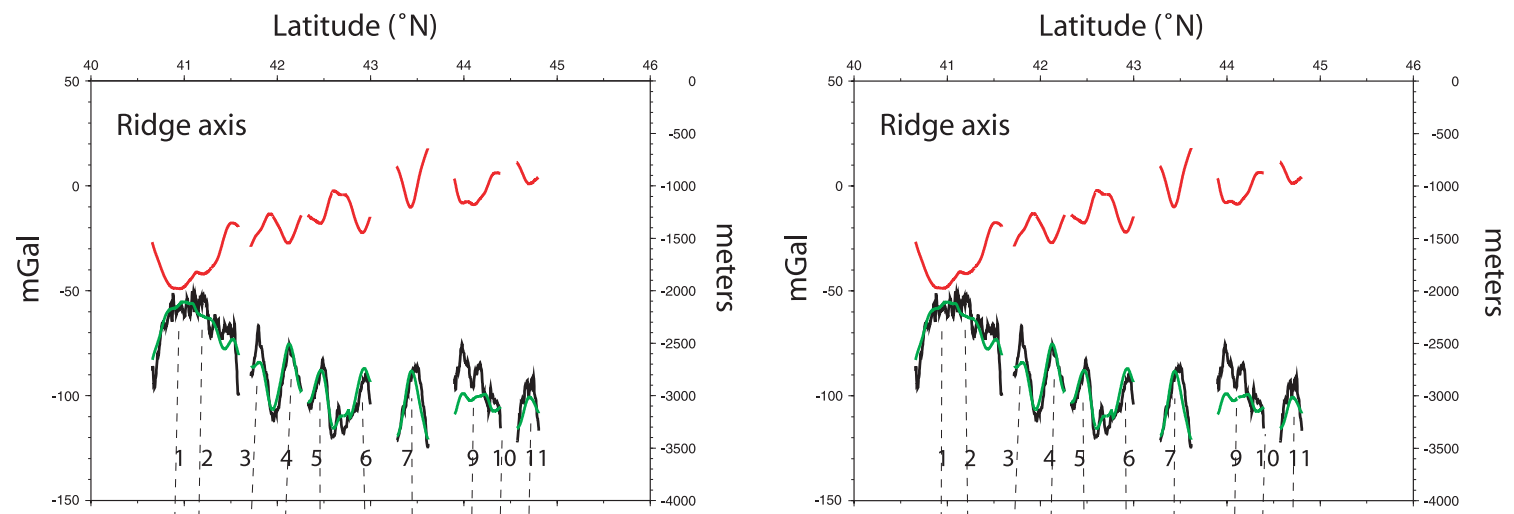

West flank

East flank
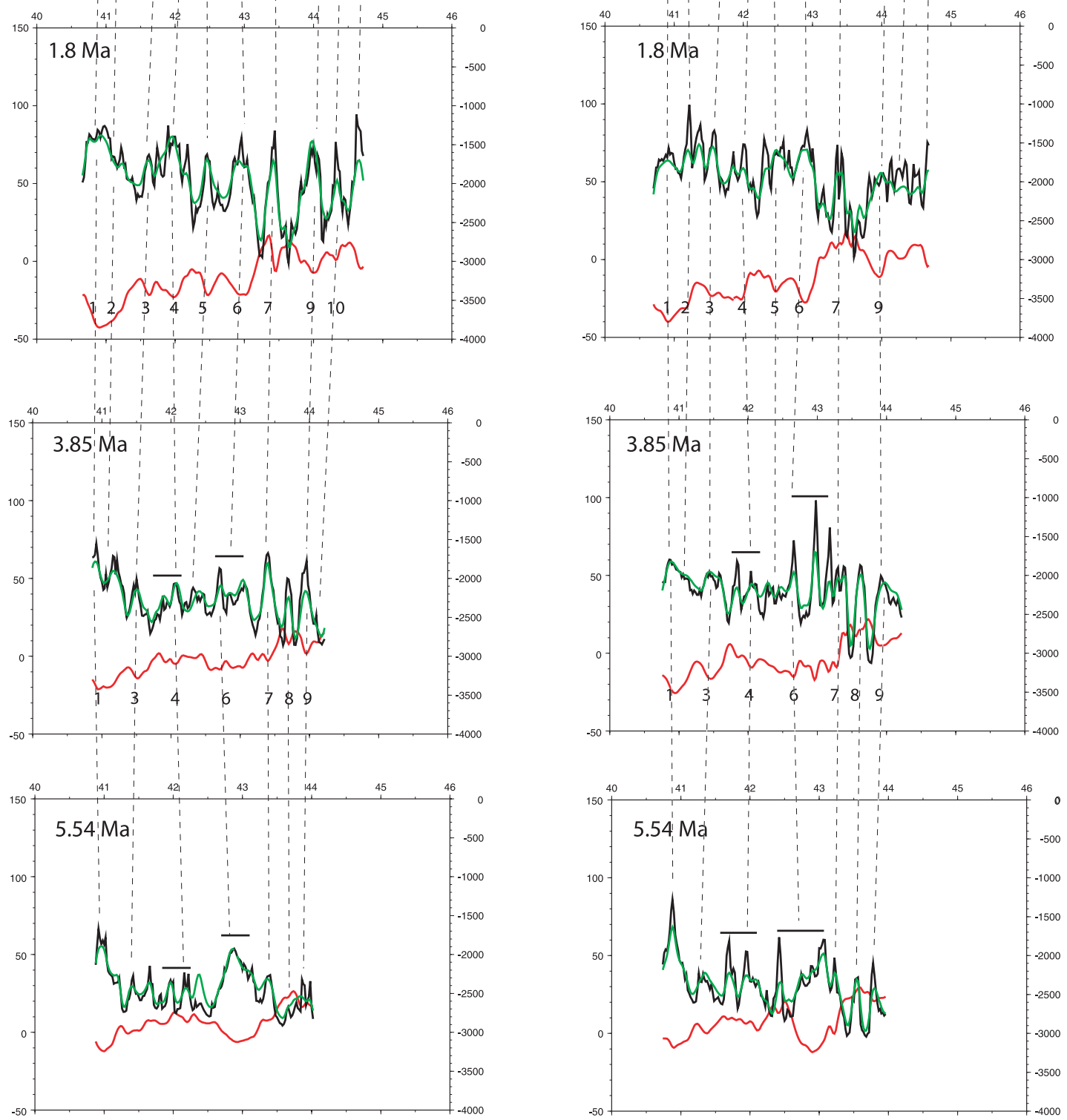

Figure 5. MBA (red), bathymetry (black), and $20 \mathrm{~km}$ filtered bathymetry (green) profiles along the axis and anomalies 2, 3, and 3A for both flanks of the MAR. Dotted lines trace the continuity between present-day and past segment centers. The horizontal lines correspond to areas where segmentation evolved fast (segments 4 and 6). Segments are numbered according to Figure 2. 
northward at a relatively high rate, while its southern limit remained stable. Segment 3 also lengthens northward and is bounded to the north by a "V" shaped discontinuity that has been propagating northward at very fast rates since anomaly 2 . North of this segment, the pattern is more complex and suggestive of highly unstable segments. The traces of three past discontinuities can be observed between anomalies $3 \mathrm{~A}$ and 2 on both ridge flanks, suggesting the existence of three segments until anomaly 2. Two of these segments merged to form the presently active segment 4 . Segment 5 lengthened relatively fast until anomaly 2 and remained stable since then. Segment 6 displays a pattern similar to segment 4 , with three past segments merging into a single presently active one. Its northern boundary corresponds to the largest axial offset of this domain $(\sim 18 \mathrm{~km})$ and to a relatively wide discontinuity which marks the northern limit of the first domain.

[13] The second domain is located between latitudes $43^{\circ} 05^{\prime} \mathrm{N}$ and $43^{\circ} 50^{\prime} \mathrm{N}$. It corresponds to a change in the trend of the ridge axis from $\mathrm{N}-\mathrm{S}$ to $\mathrm{N} 15^{\circ}$ and to a major relay zone, $85 \mathrm{~km}$ wide which shifts the ridge axis $\sim 40 \mathrm{~km}$ eastward [Goslin and the Triatnord Scientific Party, 1999]. A single $40 \mathrm{~km}-$ long stable accretion segment can be identified (segment 7). Elsewhere, the relief is dominated by small irregular basins, similar to those observed along some parts of the SWIR [Moews et al., 1998]. Two dredge hauls in this relay zone collected serpentinized peridotites. Inside the relay zone, a fossil segment center (segment 8) is observed before anomaly 2 . The third and northernmost domain lies between $43^{\circ} 50^{\prime} \mathrm{N}$ and the northern limit of the survey, $45^{\circ} \mathrm{N}$. Four segments $25-30 \mathrm{~km}$ long bounded by small axial offsets are identified (segments 9 to 11). Their morphology is similar to that of the segments south of the Azores Plateau [Thibaud et al., 1998] with the axial valley deepening toward the segment ends.

[14] The average depth of the axial valley varies from $2600 \mathrm{~m}$ for the first domain to $3000 \mathrm{~m}$ for the third and northernmost domain while that of the ridge crests varies from $800 \mathrm{~m}$ to $2000 \mathrm{~m}$, accordingly. These values show that the MAR north of the Azores Plateau is anomalously shallow when compared to the MAR south of Kane Fracture Zone, where the average axial depth is $\sim 3800 \mathrm{~m}$ [Thibaud et al., 1998]. Such shallow depths are comparable to the MAR between Pico and Hayes Fracture Zones, where the average depth of the valley ranges from $2700 \mathrm{~m}$ to $3000 \mathrm{~m}$ [Detrick et al., 1995]. The deepest part of the ridge corresponds to the wide relay zone of the central domain. Both the increasing ridge depths and the north pointing " $V$ " discontinuities may reflect a decreasing influence of the Azores plume toward the north [Goslin and the Triatnord Scientific Party, 1999].

\subsection{Mantle Bouguer Anomaly}

[15] In order to address the problem of the MAR crustal structure, we calculate the Mantle Bouguer anomaly (MBA) using the multibeam bathymetry and the merged free air anomalies discussed in section 2. The method and the parameters used for the model were discussed in section 3. However, for this detailed study, we also used seismic data to infer the thickness of the sedimentary cover [Goslin and the Triatnord Scientific Party, 1999]. Sediments are concentrated in small pockets, filling depressions between the abyssal hills. The sediment coverage is not uniform along the survey area, being generally thicker south of $43^{\circ} \mathrm{N}$. The average thickness of the sediments increase with the age of the crust, $110 \mathrm{~m}$ in average for anomaly $3 \mathrm{~A}(5.54 \mathrm{Ma})$ and only $36 \mathrm{~m}$ for anomaly 2 $(1.86 \mathrm{Ma})$. The gravity effect of the sediments is $5 \mathrm{mGal}$ at most but since they are distributed in small localized pockets, this effect will mostly contribute to the shortest wavelengths of the Mantle Bouguer anomaly.

[16] The MBA (Figure 4b) partly reflects the pattern observed in the morphology. Two domains clearly stand out on Figure 4b: south of $43^{\circ} \mathrm{N}$, large negative, roughly circular anomalies centered at the ridge axis are observed; north of $43^{\circ} 50^{\prime} \mathrm{N}$, the MBA is characterized by less negative anomalies. These two areas are separated by a broad zone of relative positive anomalies, corresponding to the large relay zone of the central domain, defined above from the ridge morphology. The MBA correlates with the segmentation inferred from the bathymetry and the more negative anomalies correspond to segments centers and to topography highs (Figure 5). The most negative anomalies, reaching -50 and $-43 \mathrm{mGal}$ are associated with segments 1 and 2, respectively. Both form a single broad negative signature with two relative minima, the strongest being associated with segment 1 . Segment 3 is also associated with a negative anomaly centered at the ridge axis and slightly asymmetric. Segment 4 has a negative axial anomaly that extends to the east flank. Segment 5 displays an elongated anomaly with three minima 
located off axis. Two off-axis symmetric minima characterize segment 6 . Inside the relay zone, the active segment 7 is also marked by a relatively negative signal of $-12 \mathrm{mGal}$ forming an elongated band easily followed off-axis and well correlated with the topographic highs. The northern domain also shows negative anomalies although the minima are systematically located off-axis. The two largest axial discontinuities of the surveyed area (near $43^{\circ} 10^{\prime} \mathrm{N}$ and the relay zone itself) are marked by strong relative positive anomalies. There is no correlation between segment length and axial MBA amplitude or between segment length and the amplitude of the axial relief for the segments of the surveyed area. The axial MBA amplitude and the axial relief, however, do correlate reasonably well $\left(\mathrm{R}^{2} \sim 0.7\right)$.

[17] In order to facilitate the comparison between topography and gravity, the bathymetry was filtered with a $20-\mathrm{km}$ low-pass filter. This removes the shortest wavelengths of the signal that are not present in the gravity data set. Profiles taken on both flanks of the MAR along isochrons 2, 3 and 3A (Figure 5) show that both the filtered topography and the MBA are roughly symmetrical and display similar patterns over the two flanks, reflecting the ridge segmentation. A long wavelength trend, with shallower topography and more negative MBA values in the south is systematically observed for all the isochrons between the axis and anomaly $3 \mathrm{~A}$.

\subsection{Crustal Structure Inferred From the Residual Mantle Bouguer Anomalies}

[18] As for the regional study presented in section 3 , we corrected the MBA from the effect of lithospheric cooling, obtaining the residual MBA or RMBA. The method was discussed in section 3 and is well suited for this part of the ridge, where large offset discontinuities are absent. For the detailed study, the age grid was constructed using the magnetic anomalies identified along the ship's tracks [Goslin and the Triatnord Scientific Party, 1999]. As the calculation of the cooling effect of the plate requires extended grids to insure the correct calculations in the Fourier domain, we included ages derived from the world ages grid of Müller et al. [1997] outside the survey area. The final age grid contains $1024 \times 1024$ points with a $2 \mathrm{~km}$ grid spacing. The effect of the thermal subsidence is also removed from the topography using the parameters described in section 3 .
[19] The residual MBA (RMBA) exemplifies the difference between the domains extending south and north of the $43^{\circ}-44^{\circ} \mathrm{N}$ relay zone (Figure 6a). As was observed above on the total MBA, the southern domain is marked by more negative anomalies than the northern domain. The most noticeable observation is the presence of strong off-axis minima in both domains, a pattern already visible (even if less evident) on the MBA. With the exception of segments 1 and 2, off-axis anomalies appear to be more negative than axial ones. Another remarkable feature is the strong signature of the discontinuities, whose relative maxima appear to dominate this part of the ridge. The general pattern appears discontinuous north of segments 1 and 2, with patches of relatively negative anomalies often symmetrically organized, different from what is observed in other areas of the MAR, where the segments more strongly resemble segments 1 and 2 .

[20] The discontinuous pattern observed on the RMBA is also visible on the residual bathymetry (Figure 6b). The removal of an average subsidence curve allows a better identification of the off-axis segmentation. The massifs associated with the ancient segment centers clearly stand out. Again, the two southernmost segments are marked by regular and relatively continuous massifs. North of segment 2, massifs are irregularly distributed and smaller in size, while the abyssal hills are wider and often disrupted by small basins. The average residual depth is $220 \mathrm{~m}$ shallower south of the relay zone than north of it. Shallower depths usually correlate with thicker crust, lower mantle densities and are associated with hotter mantle domains. Thus the average depth differences between the northern and the southern domain would correspond to higher mantle temperatures south of $43^{\circ} \mathrm{N}$. The differences observed in the RMBA and in the residual bathymetry between the northern and the southern domains thus suggest that more crust was produced south of $43^{\circ} \mathrm{N}$ in the last 5 m.y., but also that a less dense mantle is probably present beneath the ridge. Both the shallower depths and the more negative RMBA values may reflect a stronger influence of the Azores south of the relay zone for this recent period.

[21] Crustal effects and mantle effects may thus contribute to the RMBA and to the bathymetry. Both effects are linked since a higher upper mantle temperature can induce an excess in crustal production. The pronounced north-south gradient observed both along- and off-axis may be thus 

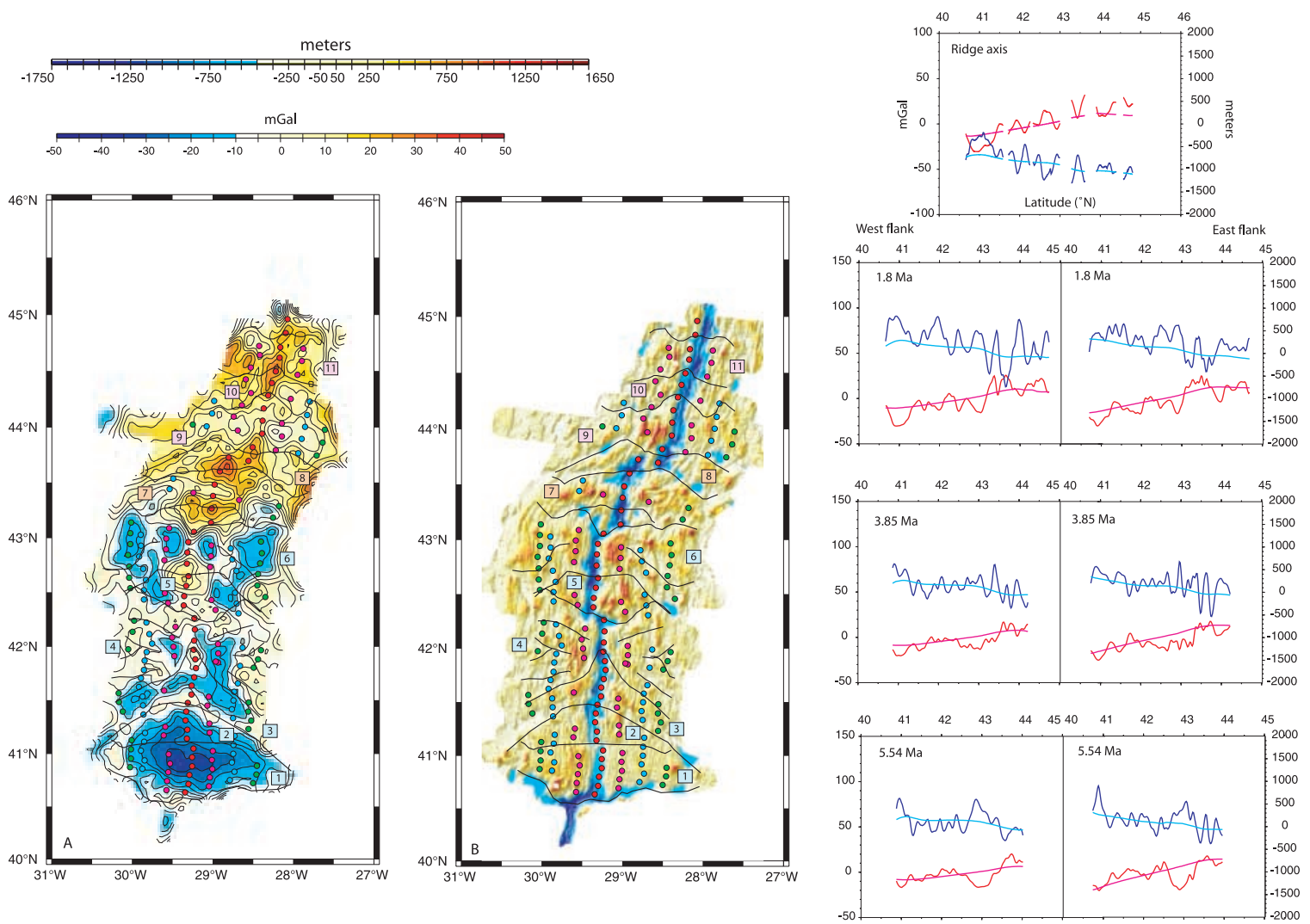

Figure 6. (a) RMBA corresponding to the MBA after the removal of the gravity effect of a cooling lithosphere. (b) Residual bathymetry after the removal of the subsidence illuminated from the north and from the west. Age identifications as in Figure 2. To the right of Figure $6 \mathrm{~b}$ are profiles along the ridge axis and anomalies 2, 3, and 3A showing the RMBA (red) and the residual bathymetry (dark blue). The long-wavelength anomalies of both signals after a 400-km low-pass filter has been applied (filtered RMBA in magenta and filtered residual bathymetry in light blue) are also shown.

partly due to a variation in the mantle density related both to the temperature gradient and to the melting process induced by the nearby plume [Ito et al., 1996]. Plume-ridge interaction models [e.g., Ito and Lin, 1995a, 1995b; Ito et al., 1996] estimate that the crustal contribution to both the topography and the MBA is $\sim 75 \%$, while the remaining $25 \%$ are due to horizontal density variations in the shallow mantle. Canales et al. [2002] proposed similar figures for the relative effects of the crust and mantle along the Galapagos spreading center from a seismic study.

[22] In order to evaluate the crustal thickness variations of this part of the MAR and in the absence of independent seismic data we chose to adopt two different models. In the first model, the whole RMBA signal is inversed in terms of crustal thickness. This model corresponds to an endmember and yields maximum crustal thickness variations, considering the mantle density to be constant. In the second model, part of the regional trend in the topography and in the gravity signal is attributed to mantle density variations. In this second model, we attempt to estimate how much of the north-south variations observed in the residual topography and in the RMBA can result from horizontal density variations in the mantle due to the effect of the Azores plume and which remaining effect can be due to differences in crustal production between the northern and southern domains. Crustal thickness variations will therefore be smaller than in model 1 .

\subsubsection{Model 1: Crustal Thickness Variations Inferred From the RMBA}

[23] The crustal thickness variations can be computed by inverting the RMBA following the method of Kuo and Forsyth [1988]. In doing so we assume 

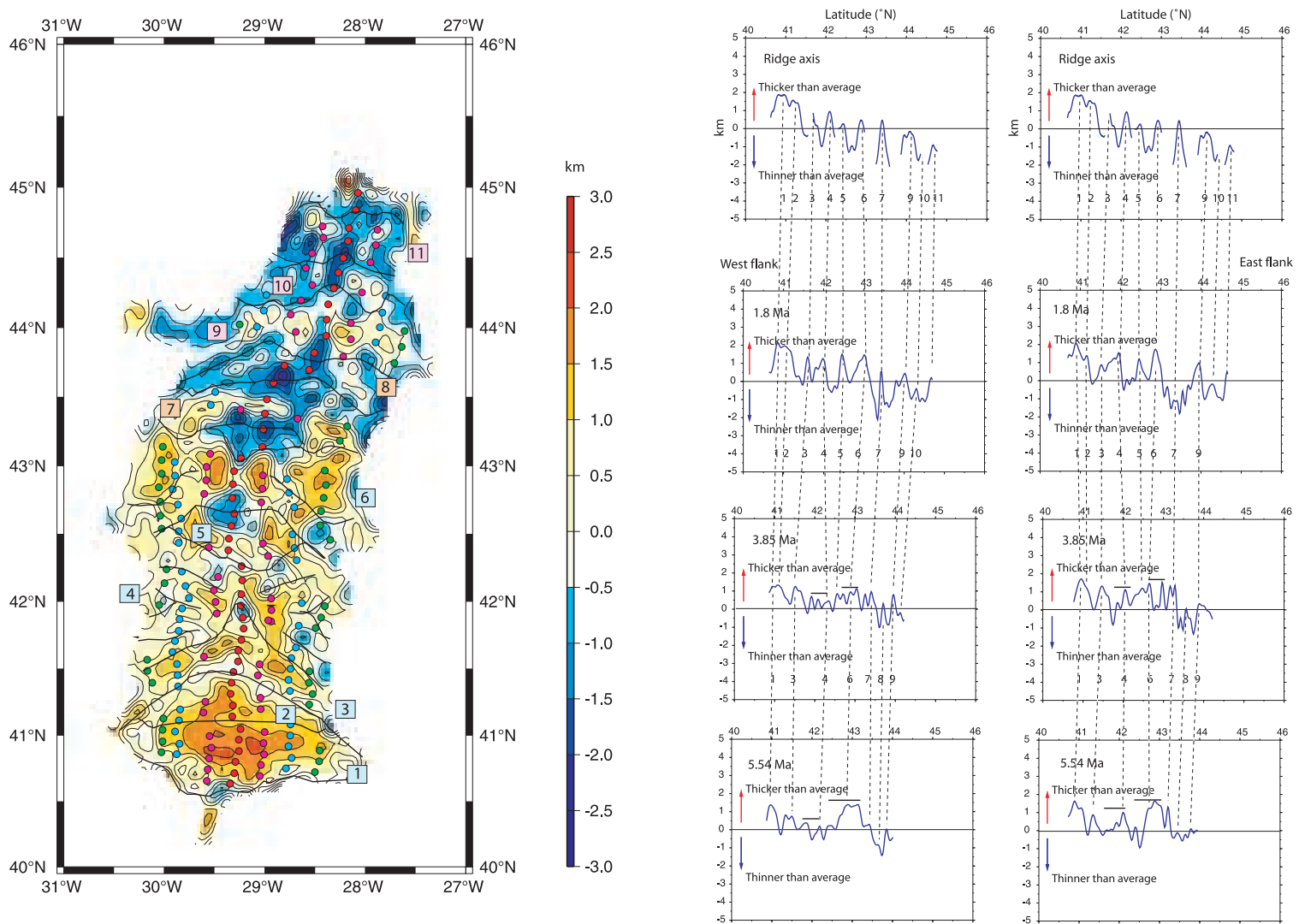

Figure 7. (left) Crustal thickness variations derived from the RMBA shown in Figure 9. Age identifications as in Figure 2. (right) Crustal thickness profiles along the axis and anomalies 2, 3, and 3A. The profiles represent variations from an average 6-km-thick crust, which corresponds to the zero-level. Values above this line correspond to crust thicker than $6 \mathrm{~km}$, while values below it correspond to crust thinner than $6 \mathrm{~km}$. Dotted lines as in Figure 5 .

that the RMBA is entirely due to variations in the crustal thickness and that the crust and mantle densities are uniform. The resulting crustal thickness pattern mimics the RMBA (Figure 7) and corresponds to the ridge segmentation. The discontinuities are marked by relatively thin crust and some form narrow and rather continuous bands, as for example south of segment 1 and between segments 2 and 3. Segment 4 shows several areas of relatively thin crust reflecting its complex history. The thinnest crust is associated with the discontinuity between segments 6 and 7, which corresponds to a $\sim 18 \mathrm{~km}$ axial offset, and to the southern limit of the relay zone. The amplitude of the crustal thickness variations over the study area is $7.1 \mathrm{~km}$. The crust underlying the southern domain is thicker by $1.1 \pm 0.7 \mathrm{~km}$ in average than the crust underlying the north domain.

[24] Most of the ridge axis is associated with relatively thin crust (Figures 7 and 8). For most of the segments, the thickest crust and highest massifs are presently located off-axis. Segments 1 and 2 display regular elongated bands of thickened crust up to anomaly $3 \mathrm{~A}$, reflecting stability of the ridge processes. The other segments display the disrupted pattern previously discussed. The ancient segment centers are associated with thicker crust. The maximum values are observed for segments 1 and 2 and for the off-axis massifs of segment 6 around anomaly 2, and the crust is generally thicker off-axis. The crustal pattern suggests discontinuous and relatively short periods of crustal production, except for segments 1 and 2. Apart from the Kurchatov Fracture Zone and the relay zone, there are no large offset discontinuities in this part of the MAR. Most of the small- or no-offset discontinuities are short-lived. Average crustal thicknesses under the axis and under the isochrones 2, 3 and 3A are close to the world average of $6 \mathrm{~km}$ [Chen, 1992] and are relatively constant and symmetric since anomaly 3A (Figures 7 and 8). Profiles of crustal thickness variations for the center of 

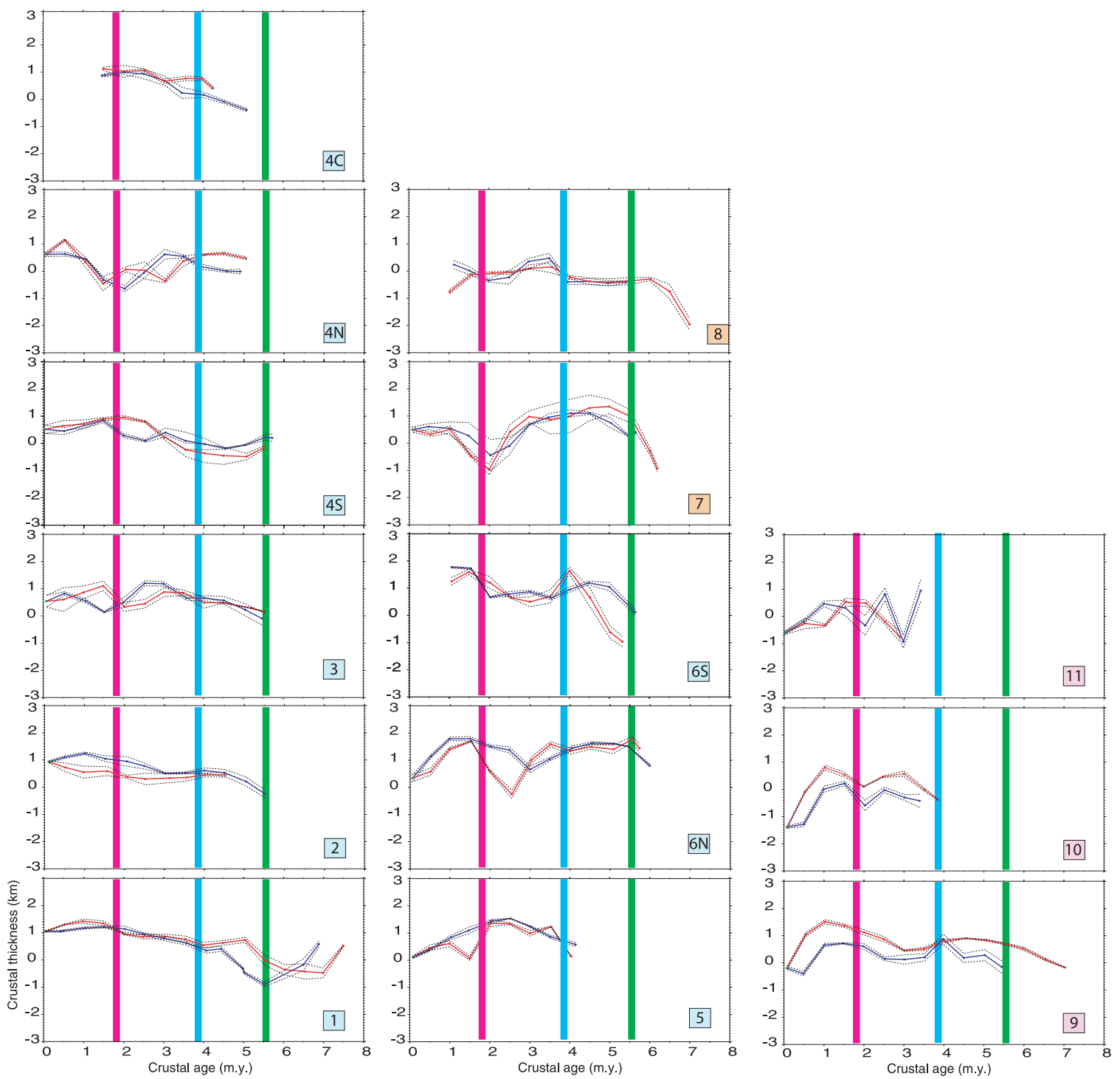

Figure 8. Crustal thickness variations through time for each segment center identified in the study area averaged over a $0.6 \mathrm{~km}$ band. As for the previous figure, the lines represent variations from an average 6-km-thick crust, which corresponds to the zero-level. The envelopes show the $1 \sigma$ error bar for the average crustal thickness. The colored bars show the location of anomalies 2, 3, and 3A. The blue profiles correspond to the west flank and the red profiles correspond to the east flank of the ridge. The segments are numbered according to Figure 2. For segment 4 the letters $\mathrm{S}, \mathrm{N}$, and $\mathrm{C}$ correspond to the southern, northern, and central parts of the segment. For segment 6 the letters $\mathrm{S}$ and $\mathrm{N}$ correspond to the southern and northern parts of the segment.

each segment identified are plotted on Figure 8. Crustal processes appear to vary individually for each segment. For most of the segments, crustal thickness variations are symmetric and display roughly the same average values for both ridge flanks, except for segments 9 and 10, where the crust observed under the west flank is thinner than that under the east flank. Segments 3 and 11 are the only segments displaying a significant asymmetry, with thick-crust episodes on the west flank corresponding to periods of thinner crust on the east flank and vice versa.

\subsubsection{Model 2: Crustal Thickness Variations Inferred From the Crustal MBA (CMBA)}

[25] A $400 \mathrm{~km}$ low-pass 3-D filter was applied to the RMBA and to the residual topography grids in order to isolate the long-wavelength component of both signals (Figures 6 (right) and 9). Cut-off 

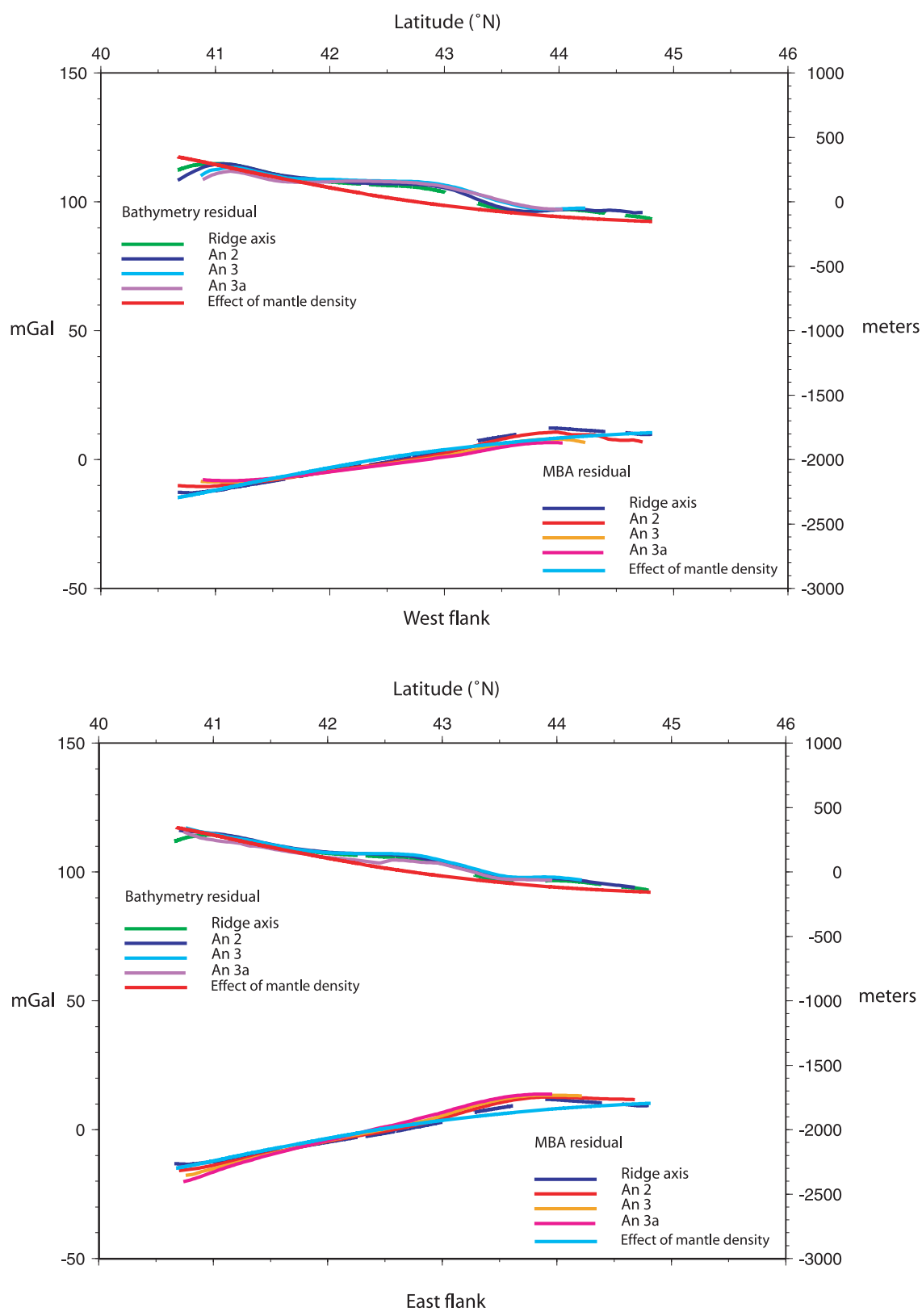

Figure 9. Long-wavelength of the RMBA and of the residual bathymetry grouped over the west flank and over the east flank of the ridge. The computed effect of a lateral density variation in the upper mantle is also shown.

wavelengths from 200 to $500 \mathrm{~km}$ were tested and the choice was determined both by a spectral analysis of the data set showing a peak around $400 \mathrm{~km}$ and by the convergence of the longwavelength signals obtained after cut-off filters above $400 \mathrm{~km}$ had been applied, showing that there is no significant variation in the longwavelength signal above this wavelength. This long wavelength component is analogous to that observed south of the Azores platform [Thibaud et al., 1998] and south and north of Iceland, and is conveniently modeled by a plume-related mantle density gradient [Ito et al., 1996]. Low values for mantle densities at the MAR axis near the Azores have also been proposed on the basis of geochemical considerations [e.g., Bourdon et al., 1996] with positive gradients away from the hot spot. Mello et al. [1999] derived an along-axis variation in the density of the uppermost mantle from Pratt isostatic compensation of the topography in order to model the long-wavelength gravity and topography signals over the north and south of the Azores. 

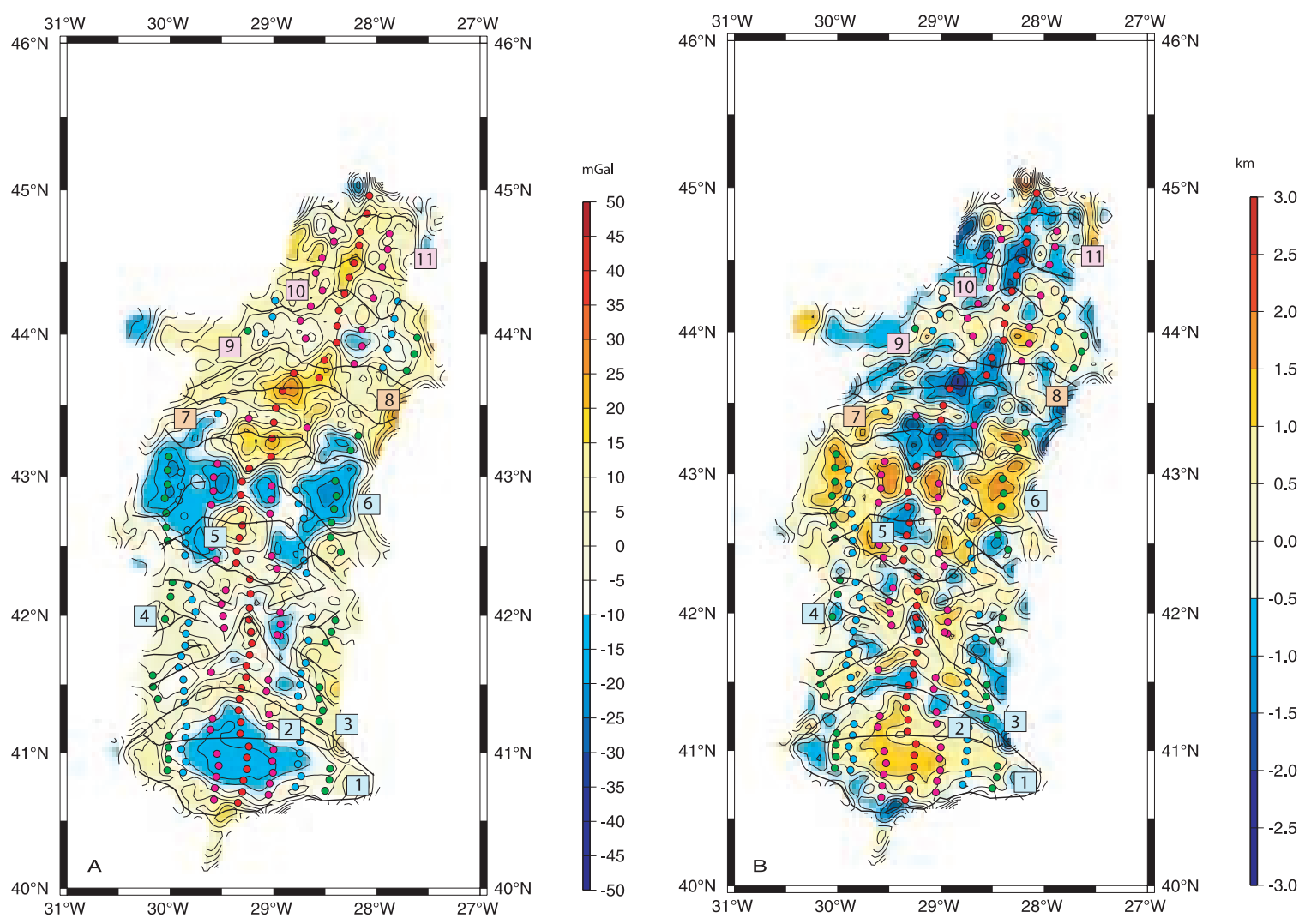

Figure 10. (a) CMBA, i.e., the residual anomaly after the removal of the gravity effect resulting from the lateral density variations in the mantle from the RMBA. Age identifications as in Figure 2. (b) Corresponding crustal thickness variations. Age identifications as in Figure 2.

[26] According to the results of published numerical models [e.g., Ito et al., 1996], we adopted in our study a Gaussian mantle density distribution which results in a steeper along-axis density variation near the Azores and to a smoother variation further away. The calculations are integrated over a $100 \mathrm{~km}$ thick mantle layer since small density variations below this depth do not have significant influence on surface values of the topography and the gravity anomalies. We did not consider the effect of density increase with depth, since this effect is small. The adopted along-axis density distribution would correspond to an excess temperature of $160^{\circ} \mathrm{C}$ in the Azores, if temperature was the only factor contributing to the density variation. A direct relationship between the best-fitting density gradient and temperature is a very simplistic approach since mantle density variations are due both to temperature effects and to melting processes [Ito et al., 1996]. Although being an upper limit, such a plume temperature excess is not significantly different from values proposed for other mantle plumes in convective models [Sleep, 1990; Ito et al., 1996]. The computed bathymetry and gravity fit the average trend of the observed signals (Figure 9). The computed mantle effect accounts for roughly $28 \%$ of the total RMBA amplitude variation, which is close to the estimates made by Ito and Lin [1995a, 1995b] and Canales et al. [2002]. This implies that part of the long wavelength RMBA and residual topography gradient north of the Azores Plateau can be due to a density variation in the mantle linked to the plume thermal effect.

[27] By removing the computed contribution of the mantle density variation from the RMBA and the residual topography we computed residual anomalies that are considered to reflect the crustal signal and are termed crustal MBA (CMBA) and crustal topography. CMBA values (Figure 10a) south of the relay zone are still more negative than values north of it, although the amplitude of the southnorth variation is reduced. The difference between the average depths of the topography between the south and the north domains is reduced to $\sim 100 \mathrm{~m}$, with the southern domain remaining shallower than the north. 
[28] The crustal thickness variations are then computed by inverting the CMBA following the method of Kuo and Forsyth [1988] as for Model 1. Again, the crustal thickness pattern corresponds to the ridge segmentation (Figure 10b). The same pattern discussed in section 4.3.1 is observed, the only difference being the average values. The amplitude of the crustal thickness variations calculated with Model 1 is $7.1 \mathrm{~km}$ while Model 2 yields an amplitude of $5.3 \mathrm{~km}$. The crust underlying the southern domain remains thicker than that of the northern domain, but the average difference is now reduced to $0.3 \pm 0.7 \mathrm{~km}$. Average crustal values remain close or slightly below $6 \mathrm{~km}$. The north south trend is thus considerably reduced, but some signal still remains, since a lateral gradient in mantle temperature will also yield higher malting rates and therefore thicker crust.

\section{Discussion}

[29] Either considering Model 1 or Model 2, the computed crustal thickness variations show that the axis is presently undergoing a period of weak magmatic production. Average crustal thickness is slightly lower than the $6 \mathrm{~km}$ world average [Chen, 1992]. Most of the paleo-segment centers correspond to relatively thicker crust, although in general these values do not exceed $7 \mathrm{~km}$. The discontinuities are underlain by thin crust $(\sim 5-$ $4 \mathrm{~km}$ ). A strong magmatic event can often be dated around anomaly 2, and another episode of high crustal production can be identified in places between anomalies 3 and 3A. Between these magmatic phases, a weaker magmatic activity, similar to what is observed today, would have occurred along most of the segments. This implies a discontinuous magmatic production along the MAR axis north of the Azores for the last 5 m.y., both north and south of the relay zone. Although the hot spot was located close to the ridge throughout this period, it apparently had no significant influence on the MAR's magmatic production north of the Azores. Even though the crust derived from both models is thicker south of the relay zone, the crustal thickness values shows that plume material has not been significantly brought to the axis since 5 m.y.

[30] The good correlation between the axial MBA amplitudes and the axial relief on one hand and between the crustal thickness variations and the topography on the other hand indicates that accretion north of the Azores is largely focused under segment centers, as observed along other sections of the MAR. The small size of the massifs suggests, however, that although the melt upwelling is focused, it is also relatively weak and that each magmatic phase is short. Crustal production is consequently focused, but since each pulse is short-lived, there is not enough melt to produce broad, large areas of thick crust, except for segments 1 and 2 .

[31] Although the crustal pattern reveals a relatively weak and discontinuous magmatic production north of the Azores since anomaly 3A, the bathymetry and gravity gradients show that the MAR is still under the influence of the plume. This influence is probably limited to the presence of a slightly hotter upper mantle, inducing higher melting rates and therefore producing slightly thicker crust south of the $43^{\circ} 40^{\prime} \mathrm{N}$ relay zone. Probably, at this late stage of the plume-ridge interaction, there is no more significant input of plume material at the axis. This could be an explanation for the apparent discrepancy between the along-axis extension of the chemical signature of the Azores plume and its thermal influence, the latter being reflected by the long-wavelength of both the topography and the gravity. North of the Azores platform, the isotopic signature of the plume at the ridge axis ends near the Kurchatov Fracture Zone [Yu et al., 1997; Dosso et al., 1999], while the thermal gradient apparently extends to $43^{\circ} 40^{\prime} \mathrm{N}$ and maybe even further [Schilling et al., 1983; Mello et al., 1999]. The plume material itself would probably no longer be reaching the ridge in large enough amounts to spread over long distances along the axis. But the plume thermal influence, materialized as a mantle density gradient, is still present and shapes both the regional bathymetry and gravity. The lack of off-axis rock samples precludes the assessment of the importance of a possible input of mantle material along the ridge axis in the past, but it is probable that the topographic high, located near anomaly 5, was formed by the arrival at the axis of enriched plume material.

[32] The presence of a slightly hotter mantle beneath the ridge bear a small influence on the accretion processes at segment level. Although the average thickness of the crust is larger south of the relay zone, possibly reflecting slightly higher upper mantle temperatures, the crustal pattern is not different north and south of this discontinuity. When these temperatures happen to be much higher than the average mantle, melting rates will increase. As a consequence, long magmatic phases 
will contribute to produce thick crust and high topography, such as the plateau now located around anomaly 5. During "normal" mantle temperature periods, other factors, such as the geometry of the ridge axis, may play a more important role.

[33] The asymmetry of the Azores influence north and south of the Azores platform persists since at least anomaly 5 . Although the magmatic pulse that emplaced the Princess Alice Plateau on axis south of the platform has a counterpart north of it, the pulse propagated mainly southward, building oblique ridges and the Jussieu Plateau [Escartin et al., 2001]. We do not find evidence of an equivalent northward propagation of this pulse. The axial domain north and south of the Azores platform also show significant differences. Detrick et al. [1995] found crustal thickness values reaching $9 \mathrm{~km}$ for the segments immediately south of the platform and $10 \mathrm{~km}$ for segments located in the platform, where the influence of the hot spot is stronger. They attribute most of the crustal thickness variations for segments south of Pico FZ to focusing of the accretion related to ridge offsets and segment lengths. However, a gradient of $0.5 \mathrm{~km} /{ }^{\circ}$ is attributed to the thermal influence of the Azores [Detrick et al., 1995; Hooft et al., 2000]. Even considering Model 1, crustal thicknesses north of the Azores platform do not exceed 7-8 $\mathrm{km}$ for segment 1 , the most robust of the area, and are between 5 to $7 \mathrm{~km}$ for the other segments. The hot spot flow appears thus to be mainly directed southward, creating a long-term asymmetry is the accretion processes at the MAR.

\section{Conclusions}

[34] The crustal structure inferred from gravity data along the Mid-Atlantic Ridge north of the Azores between anomaly $3 \mathrm{~A}$ and the present suggests that the plume influence on the accretion processes has been very limited in the last 5 m.y. Average crustal thickness is close to the $6-\mathrm{km}$ world average and a normal slow ridge type of segmentation prevailed during this period. We considered two different models to estimate crustal thickness variations. In Model 1, all the gravity signal is inverted in terms of crustal thickness variations, thus yielding thicker crust south of the $43^{\circ} 40^{\prime} \mathrm{N}$ relay zone. In Model 2, part of the longwavelength trends of both the topography and the MBA are attributed to a weak thermal influence of the hot spot. In this model, the crustal average values south of the $43^{\circ} 40^{\prime} \mathrm{N}$ relay zone remain slightly higher. In both cases, this suggests that the thermal influence of the Azores plume is weaker north of this latitude.

[35] Excess temperature and material flow from the plume around anomaly 5 resulted in the creation of the northern counterpart of the Princess Alice Plateau, as a consequence of excess crustal production at the ridge axis. After this event, the influence of the plume at the axis decreased quickly, resulting in the rifting of the plateau and the creation of a "normal" slow ridge segmentation pattern. For most of the area, crustal production is discontinuous and relatively weak and there is no significant difference in the segmentation pattern south and north of the relay zone, suggesting that the accretion is mainly controlled by local processes at the scale of individual segments.

\section{Acknowledgments}

[36] We are grateful to captain Tredunit and his crew for their seamanship and to the GENAVIR staff for their help on acquiring and processing the data during the TRIATNORD cruise. Figures were drawn using the GMT software of Wessel and Smith [1998]. Comments by Peter Vogt and an anonymous reviewer significantly contributed to improve the quality of this paper. This study was funded by CNRS-INSU through the "Océans" program. This is contribution 1020 of IUEM.

\section{References}

Bourdon, B., C. H. Langmuir, and A. Zindler (1996), Ridgehotspot interaction along the Mid-Atlantic Ridge between $37^{\prime} 30^{\prime}$ and $40^{\prime} 30^{\prime} \mathrm{N}$ : The U-Th disequilibrium evidence, Earth Planet. Sci. Lett., 142, 175-189.

Canales, J. P., G. Ito, R. S. Detrick, and J. Sinton (2002), Crustal thickness along the western Galapagos Spreading Center and the compensation of the Galapagos hotspot swell, Earth Planet. Sci. Lett., 203, 311-327.

Cannat, M., et al. (1999), Mid-Atlantic Ridge - Azores hot spot interactions: Along-axis migration of a hot spot-derived magmatic pulse 14 to 4 myrs ago, Earth Planet. Sci. Lett., $173,257-269$.

Chen, Y. (1992), Oceanic crustal thickness versus spreading rate, Geophys. Res. Lett., 19, 753-756.

Detrick, R. S., H. D. Needham, and V. Renard (1995), Gravity anomalies and crustal thickness variations along the MidAtlantic Ridge between $33^{\circ} \mathrm{N}$ and $40^{\circ} \mathrm{N}, J$. Geophys. Res., 100, 3767-3787.

Detrick, R. S., J. M. Sinton, G. Ito, J. P. Canales, M. Behn, T. Blacic, B. Cushman, J. E. Dixon, D. W. Graham, and J. J. Mahoney (2002), Correlated geophysical, geochemical, and volcanological manifestations of plume-ridge interaction along the Galápagos Spreading Center, Geochem. Geophys. Geosyst., 3(10), 8501, doi:10.1029/2002GC000350.

Dosso, L., H. Bougault, C. Langmuir, C. Bollinger, O. Bonnier, and J. Etoubleau (1999), The age and distribution of mantle heterogeneity along the Mid-Atlantic Ridge (31-41 degrees N), Earth Planet. Sci. Lett., 170, 269-286. 
Escartin, J., M. Cannat, G. Pouliquen, A. Rabain, and J. Lin (2001), Crustal thickness of V-shaped ridges south of the Azores: Interaction of the Mid-Atlantic Ridge $\left(36^{\circ}-39^{\circ} \mathrm{N}\right)$ and the Azores hot spot, J. Geophys. Res., 106, 21,71921,735.

Gente, P., R. Pockalny, C. Durand, C. Deplus, M. Maia, G. Ceuleneer, C. Mével, M. Cannat, and C. Laverne (1995), Characteristics and evolution of the segmentation of the MidAtlantic ridge between $20^{\circ} \mathrm{N}$ and $24^{\circ} \mathrm{N}$ during the last 10 million years, Earth Planet. Sci. Lett., 129, 55-71.

Gente, P., J. Dyment, M. Maia, and J. Goslin (2003), Interaction between the Mid-Atlantic Ridge and the Azores hot spot during the last 85 Myr: Emplacement and rifting of the hot spot-derived plateaus, Geochem. Geophys. Geosyst., 4(10), 8514, doi:10.1029/2003GC000527.

Goslin, J., and Triatnord Scientific Party (1999), Extent of Azores plume influence on the MAR north of the hotspot, Geology, 27, 991-994.

Goslin, J., J.-L. Thirot, O. Noel, and J. Francheteau (1998), Slow-ridge/hotspot interactions from global gravity, seismic tomography and ${ }^{87} \mathrm{Sr} /{ }^{86} \mathrm{Sr}$ isotope data, Geophys. J. Int., 135, $700-710$

Hooft, E. E. E., R. S. Detrick, D. R. Toomey, J. A. Collins, and J. Lin (2000), Crustal thickness and structure along three contrasting spreading segments of the Mid-Atlantic Ridge, $33.5^{\circ}-35^{\circ} \mathrm{N}$, J. Geophys. Res., 105, 8205-8226.

Ito, G., and J. Lin (1995a), Mantle temperature anomalies along the present and paleoaxes of the Galapagos spreading center as inferred from gravity analyses, J. Geophys Res., 100, 3733-3745.

Ito, G., and J. Lin (1995b), Oceanic spreading center-hotspot interactions: constraints from along-isochron bathymetric and gravity anomalies, Geology, 23, 657-660.

Ito, G., J. Lin, and C. W. Gable (1996), Dynamics of mantle flow and melting at a ridge-centered hotspot: Iceland and the Mid-Atlantic Ridge, Earth Planet. Sci. Lett., 144, 53-74.

Kincaid, C., G. Ito, and C. Gable (1995), Laboratory investigation of the interaction of off-axis mantle plumes and spreading centres, Nature, 376, 758-761.

Kincaid, C., J. G. Schilling, and C. Gable (1996), The dynamics of off-axis plume-ridge interaction in the uppermost mantle, Earth Planet. Sci. Lett., 137, 29-43.

Kingsley, R. H., and J.-G. Schilling (1998), Plume-ridge interaction in the Easter-Sala y Gomez seamount chain-Easter Microplate system: $\mathrm{Pb}$ isotope evidence, J. Geophys. Res., 103, 24,159-24,177.

Kuo, B. Y., and D. W. Forsyth (1988), Gravity anomalies of the ridge-transform system in the south Atlantic between 30 and $31^{\circ} \mathrm{S}$ : Upwelling centers and variations in crustal thickness, Mar. Geophys. Res., 10, 205-232.

Kurz, M. D., W. J. Jenkins, J. G. Schilling, and S. R. Hart (1982), Helium isotopic variations in the mantle beneath the central North Atlantic Ocean, Earth Planet. Sci. Lett., $58,1-14$.

Maia, M. (2006), Comparing the use of ship and satellite data for geodynamic studies, paper presented at ESA Symposium 15 Years of Progress in Radar Altimetry, Eur. Space Agency, Venice, Italy, 12 - 18 March.

Maia, M., and J. Arkani-Hamed (2002), The support mechanism of the young Foundation seamounts inferred from bathymetry and gravity, Geophys. J. Int., 149(1), 190-210.

Maia, M., and P. Gente (1998), Three-dimensional gravity and bathymetry analysis of the Mid-Atlantic Ridge between $20^{\circ} \mathrm{N}$ and $24^{\circ} \mathrm{N}$ : Flow geometry and temporal evolution of the segmentation, J. Geophys. Res., 103(B1), 951-974.
Maia, M., et al. (2000), The Foundation Seamounts-Pacific Antarctic Ridge interaction: A case study of a ridge approaching a hotspot, Mar. Geol., 167, 61-84.

Maia, M., C. Hémond, and P. Gente (2001), Contrasted interactions between plume, upper mantle, and lithosphere: Foundation chain case, Geochem. Geophys. Geosyst., 2(7), doi:10.1029/2000GC000117.

Mello, S. L. M., J. R. Cann, and C. M. R. Fowler (1999), Anomalous mantle at $45^{\circ} \mathrm{N}$ Mid-Atlantic Ridge?, J. Geophys. Res., 104(B12), 29,335-29,350.

Moews, D., N. R. Grindlay, J. A. Madsen, C. RommevauxJestin, and J. Sclater (1998), A different pattern of ridge segmentation and mantle Bouguer gravity anomalies along the ultra-slow spreading Southwest Indian Ridge $\left(15^{\circ} 30^{\prime} \mathrm{E}\right.$ to $25^{\circ}$ E), Earth Planet. Sci. Lett., 161, 243-253.

Morgan, W. J. R. (1978), Darwin, Amsterdam. . A s second type of hotspot island, J. Geophys. Res., 85, 5355-5360.

Müller, R. D., W. R. Roest, J.-Y. Royer, L. M. Gahagan, and J. G. Sclater (1997), Digital isochrons of the world's ocean floor, J. Geophys. Res., 102, 3211-3214.

Pan, Y., and R. Batiza (1998), Major element chemistry of volcanic glasses from the Easter seamount chain: Constraints on melting conditions in the plume channel, J. Geophys. Res., 103, 5287-5304.

Pariso, J. E., J.-C. Sempéré, and C. Rommevaux (1995), Temporal and spatial variations in crustal accretion along the Mid-Atlantic Ridge $\left(29^{\circ}-31^{\circ} 30^{\prime} \mathrm{N}\right)$ over the last 10 m.y.: Implications from a three-dimensional gravity study, J. Geophys. Res., 100, 17,781-17,794.

Parsons, B. E., and J. G. Sclater (1977), An analysis of the variation of ocean floor bathymetry and heat flow with age, J. Geophys. Res., 82, 803-827.

Phipps Morgan, J., and D. W. Forsyth (1988), Three-dimensional flow and temperature perturbations due to a transform offset: effects on oceanic crust and upper mantle structure, J. Geophys. Res., 93, 2955-2966.

Ribe, N. (1996), The dynamics of plume-ridge interaction: 2. Off-axis plumes, J. Geophys. Res., 101, 16,19516,204 .

Ribe, N., U. R. Christensen, and J. Theissing (1995), The dynamics of plume-ridge interaction, 1: Ridge centered plumes, Earth Planet. Sci. Lett., 134, 155-168.

Ribe, N. M., and W. L. Delattre (1998), The dynamics of plume-ridge interaction-III. The effects of ridge migration, Geophys. J. Int., 133, 511-518.

Rommevaux, C., C. Deplus, P. Patriat, and J.-C. Sempéré (1994), Three-dimensional gravity study of the Mid-Atlantic ridge: Evolution of the segmentation between $28^{\circ}$ and $29^{\circ} \mathrm{N}$ during the last 10 m.y., J. Geophys. Res., 99(B2), 30153030 .

Sandwell, D. T., and W. H. F. Smith (1997), Marine gravity anomaly from Geosat and ERS 1 satellite altimetry, J. Geophys. Res., 102(B5), 10,039-10,054.

Schilling, J. G. (1975), Azores mantle blob: Rare-earth evidence, Earth Planet. Sci. Lett., 25, 103-115.

Schilling, J.-G. (1985), Upper mantle heterogeneities and dynamics, Nature, 314, 62-67.

Schilling, J. G. (1991), Fluxes and excess temperatures of mantle plumes inferred from their interaction with migrating mid-ocean ridges, Nature, 352, 397-403.

Schilling, J. G., R. Kingsley, and M. Bergeron (1977), Rare earth abundances in DSDP sites 332, 334 and 335, and inferences on the Azores mantle blob activity with time, Initial Rep. Deep Sea Drill. Proj., 37, 591-598.

Schilling, J.-G., M. Zajac, R. Evans, T. Johnston, W. White, J. D. Devine, and R. Kingsley (1983), Petrology and chemical 
variations along the Mid-Atlantic Ridge from $29^{\circ} \mathrm{N}$ to $73^{\circ} \mathrm{N}$, Am. J. Sci., 283, 210-586.

Sleep, N. (1990), Hotspots and mantle plumes: some phenomenology, J. Geophys. Res., 95, 6715-6736.

Stein, C. A., and S. Stein (1992), A model for the global variation in oceanic depth and heat flow in lithospheric age, Nature, 359, 123-129.

Thibaud, R., P. Gente, and M. Maia (1998), A systematic analysis of the Mid-Atlantic Ridge morphology and gravity between $15^{\circ} \mathrm{N}$ and $40^{\circ} \mathrm{N}$ : Constraints of the thermal structure, J. Geophys. Res., 103, 223-243.

Vogt, P. R. (1976), Plumes, subaxial pipe flow and topography along the mid-oceanic ridge, Earth Planet. Sci. Lett., 29, $309-325$.

Vogt, P. R. (1979), Global magmatic episodes: new evidence and implications for the steady-state mid oceanic ridge, Geology, 7, 93-98.
Wessel, P., and W. H. F. Smith (1998), New improved version of Generic Mapping Tools released, Eos Trans. AGU, 79(47), 579.

White, W. M., and J. G. Schilling (1978), The nature and origin of geochemical variation in the Mid-Atlantic Ridge basalts from the central North Atlantic, Geochim. Cosmochim. Acta, 42, 1501-1516.

White, W. M., J. G. Schilling, and S. R. Hart (1976), Evidence for the Azores mantle plume from strontium isotopes geochemistry of the central North Atlantic, Nature, 263, 659663.

Yu, D., D. Fontignie, and J.-G. Schilling (1997), Mantle plume-ridge interactions in the central North Atlantic: A $\mathrm{Nd}$ isotope study of Mid-Atlantic Ridge basalts from $30^{\circ} \mathrm{N}$ to $50^{\circ} \mathrm{N}$, Earth Planet. Sci. Lett., 146, 259-272. 